\title{
Composition, abundance and biomass of the benthic fish fauna from the Guaritico river of a Venezuelan floodplain
}

\author{
C. Lasso ${ }^{1}$ \\ J. Castroviejo 2
}

Keywords : Fish composition, abundance, biomass, benthic fish, floodplain systems, Guaritico River, Venezuela.

The compositon, abundance and biomass of the benthic fish fauna were studied along a $6 \mathrm{~km}$ stretch of the Guaritico River. This water course is located in the western plains of Venezuela and belongs to the Apure River floodplain system. Monthly collections from June, 1990 to January, 1991 were made by means of a small trawling apparatus rigged to dugout canoes according to the design of López-Rojas et al. (1984). 42 fish species were identified with a dominance of species from the orders Siluriformes and Gymnotiformes. The fish assemblage differed markedly from other Venezuelan river systems. Seasonally, higher diversity and evenness were observed at the high water phase while the abundance, relative biomass and CPUE were higher at low water.

\section{Composition, abondance et biomasse des poissons benthiques dans la rivière de plaine Guaritico du Vénézuela}

Mots clés : Abondance, biomasse, poissons benthiques, système de plaine d'inondation, rivière Guaritico, Vénézuela.

La composition, l'abondance et la biomasse de la faune pisciaire benthique ont été étudiées sur un tronçon de $6 \mathrm{~km}$ de la rivière Guaritico. Ce système se situe dans les plaines occidentales du Vénézuela et appartient au réseau hydrographique de la rivière Apure. Des récoltes mensuelles de juin 1990 à janvier 1991 ont été faites à partir de pirogues équipées d'un chalut (modèle Lopez-Rojas et al. 1984).

Sur les 42 espèces de poissons identifiées prédominent les Siluriformes et Gymnotiformes. L'association pisciaire diffère nettement de celle des autres systèmes de rivière du Vénézuela. Les plus grandes diversité et équitabilité ont été observées pendant la période de hautes eaux alors que l'abondance, la biomasse relative et la capture par unité d'effort (CPUE) étaient les plus fortes en période d'étiage.

\section{Introduction}

The study of the fish communities associated with the main channel of Venezuelan rivers began in 1978 with the expedition of the research vessel " Eastward s to the Lower Orinoco. The results revealed the presence of a fish fauna practically unknown up to that time. During the expedition, a trawling apparatus was designed to sample in shallower areas. The results of the efficiency of this gear were published by López-Rojas et al. (1984). Similar collections

1. Asociación Amigos de Doñana, 2182,41080 Sevilla, España \& Museo Historia Natural La Salle, 1930, Caracas 1010-A, Venezuela.

2. Asociación Amigos de Doñana, 2182, 41080 Sevilla, España. were carried out in the Napo River (Ecuador) between 1981-1983 (Stewart et al. 1987). Collections were later made in the Orinoco River Delta using experimental trawling nets (Cervigón 1982, 1985, Cervigón \& Novoa 1988, Novoa 1982, 1986, Novoa \& Cervigón 1982, Ponte 1990, Ramos et al. 1982).

Systematic research on the taxonomic, ecological and fishery aspects of the benthic fish fauna of the Apure River began in 1983 (Castillo 1988, MachadoAllison 1987, Marrero 1984, 1990, Provenzano \& Castillo 1984, Provenzano et al. $1984 \mathrm{a}, \mathrm{b}, \mathrm{c})$. This paper reports the results of the research carried out in the Guaritico River (Apure River basin). In 1989, the river was declared a part of a specially protected wildlife area. The objectives of our research were : 1) to determine the species composition of the 
fish fauna associated with the bottom of the river in order to make comparisons with other similar systems ; 2) to quantify the abundance, biomass, and catch per unit effort (CPUE) determined for the first time by means of the apparatus designed by López-Rojas et al. (1984).

\section{Study area}

The study was made on the last $6 \mathrm{~km}$ stretch of the Guaritico River (locally known as caño Guaritico) before its confluence with the Apure River (Fig. 1). The Guaritico River is located on the upper section of the Apure River Basin (Ramia 1972) in a

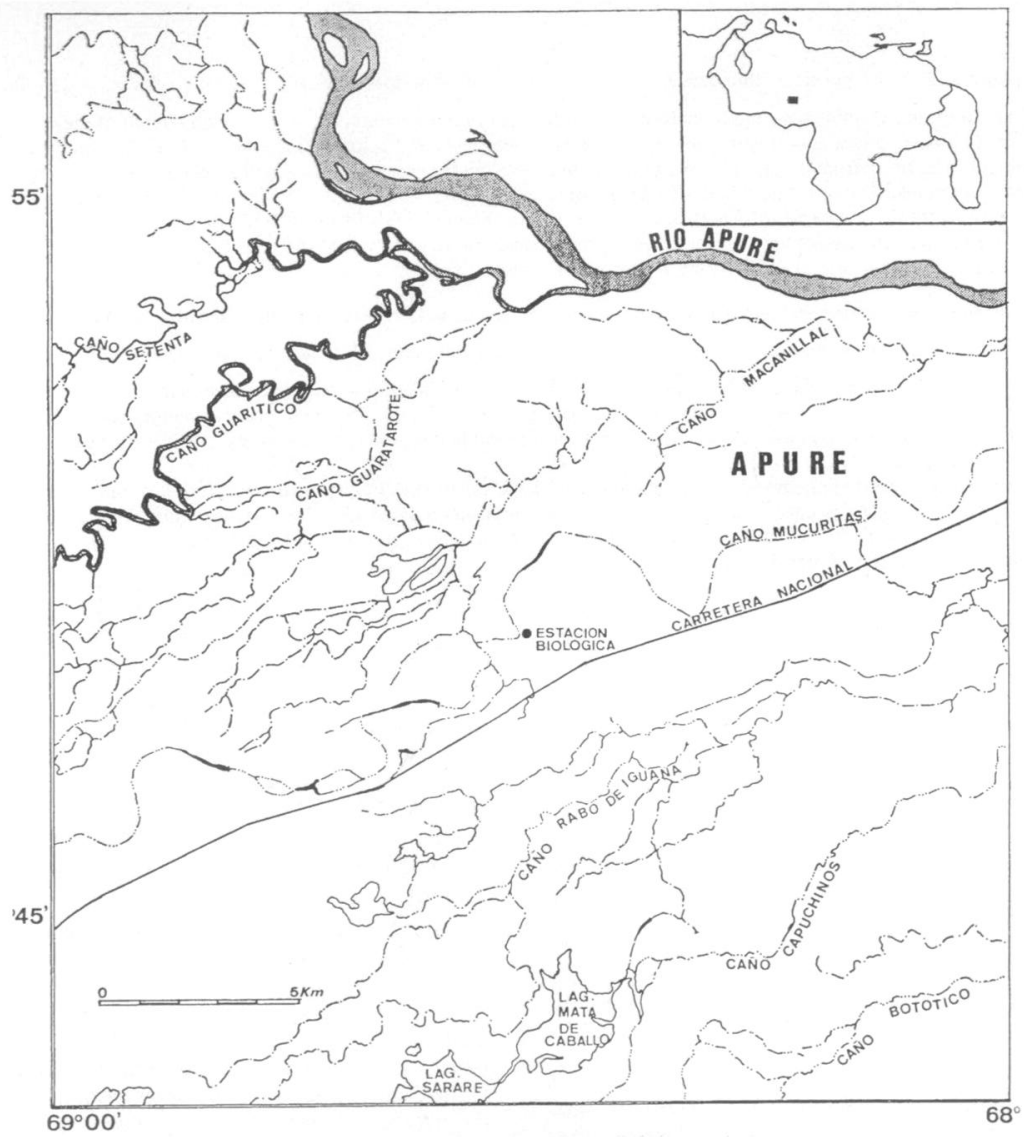

Fig. 1. Study area (dots indicate the studied river section).

Fig. 1. Carte du réseau hydrographique du Rio Apure avec, en pointillés, la section de rivière ètudiée. 
region of seasonally flooded savannas (Scharger \& González 1973, Welcomme 1979). The climatology of the area shows two contrasting periods; the dry season, which extends from November to April and the rainy season, which extends from May to October. These climatic conditions lead to two hydrometric periods : low waters (December-May) and high waters (June-November) (Fig. 2). In this study, collections of fish were made during both periods.

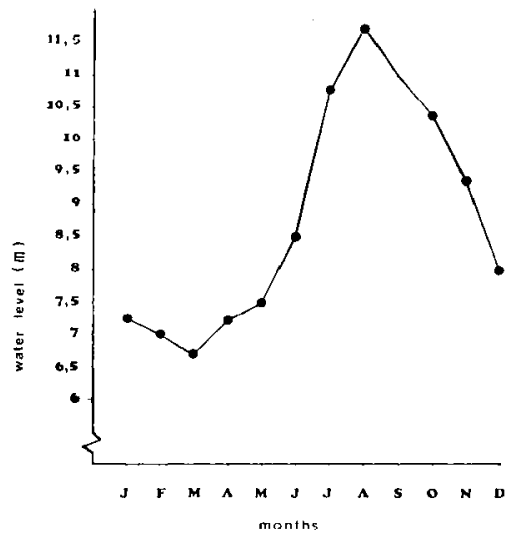

Fig. 2. Water level variations of the Guaritico River (1990).

Fig. 2. Variations du niveau de l'eau de la riviére Guaritico (1990).

During 1990, mean monthly air temperature ranged between $25.1^{\circ} \mathrm{C}$ (July) and $28.9^{\circ} \mathrm{C}$ (April). The Guaritico River supports a seasonally inundated gallery forest. The most representative tree species are Nectandria pichurini (H.B.K.) Mez, and Dugnetia riberensis Arist. On the river side next to the gallery forest, there is also a tree community known locally as "mangle », dominated by Coccoloba obtusifolia Jacq. (Castroviejo \& López 1985). According to Sioli's classification of Amazonian river waters, the Guaritico River shows clear-waters characterized by a smaller concentration of suspended solids and a higher water transparency than white-waters. Ranges for $\mathbf{p H}$, water temperature, and conductivity were $: 6.0-7.8 \mathrm{pH}$ units ; $28-32^{\circ} \mathrm{C}$; and 19.4-21.9 $\mu$ S.cm-1, respectively. Water transparency (Secchi) showed seasonal oscillations during the year and was generally higher near the confluence of the Guaritico with the Apure River. Water transparency was $25 \mathrm{~cm}$ at the end of the dry season and $20 \mathrm{~cm}$ at the beginning of the rainy season. The bottom of the channel showed the two types of clays (grey and red) described by Marrero (1990) for the Apure River.

\section{Materials and Methods}

Monthly collections were made during the high and low water periods between June 1990 and January 1991. Collections were made with a trawling fishing apparatus adapted to dugout canoes according to the design made by López-Rojas et al. (1984). Each trawling lasted for $10 \mathrm{~min}$, covering a mean distance of 147 m., at depths ranging from 2-10 m (Table 1). Catches were preserved with formaldehyde in the field. At the Laboratory, fishes were identified, weighed and measured. Species abundance was estimated with respect to the total fishes caught monthly. Diversity $\left(\mathrm{H}^{\prime}\right)$ was calculated by the Shannon-Weaver index (1949) and the evenness ( $\left.V^{\prime}\right)$ was determined as the inverse value of $\mathrm{H}^{\prime}$ max. Species biomass was calculated as the percentage in weight with respect to the total fish caught and also in terms of $\mathrm{kg} . \mathrm{ha}^{-1}$. The latter value and density (ind. ha-1) refer to the area covered by a 10 min trawling effort. The CPUE is expressed as $\mathrm{kg}$.ha.hour ${ }^{-1}$.

\section{Results}

\subsection{Fish species}

42 species from 5 orders, 13 families and 38 genera were identified (Table 2). With $26 \operatorname{spp}(61 \%)$ the Siluriformes were the best represented group, followed by the Gymnotiformes (11 spp., $26.2 \%$ ), and by the Rajiformes, Perciformes, and Pleuronectiformes which together represented $12 \%$ ( $5 \mathrm{spp}$.) of the identified species (Table 3). The dominant families were the Loricariidae, Pimelodidae, and Apteronotidae with 10,9 and 7 species, respectively. Four taxa were identified only to the generic level (Potamotrygon sp., Hemiancistrus sp., Duopalatinus sp., and Rhamphichthys sp.). A new genus and species from the family Loricariidae was recorded (Provenzano F., pers. comm.) as well as a new species from the genus Porotergus (Apteronotidae). Aphanoturulus frankei (Loricariidae) represents a new record for the Venezuelan fish fauna. Before our report, this species was known only from the Ucayali River Basin in Peru. 
Table 1. Total number of trawls, effective trawls and time of trawling .Period: June, 1990 - January, 1991. Tableau 1. Nombre total de chaluts, chaluts efficaces, et durée de chalutage. Période : juin 1990 - janvier 1991.

\begin{tabular}{lccccccc}
\hline MONTHS & JUNE & JULY & AUGUST & SEPTEMBER & OCTOBER & NOVEMBER DECEMBER & JANUARY \\
\hline $\begin{array}{l}\text { Number of trawls } \\
\begin{array}{l}\text { Number of efective } \\
\text { trawls }\end{array}\end{array}$ & 13 & 9 & 18 & 12 & 12 & 18 & 11 \\
$\begin{array}{l}\text { total trawls } \\
\text { (minutes) }\end{array}$ & 12 & 9 & 18 & 11 & 11 & 16 & 11 \\
\hline
\end{tabular}

Table 2. List of fish species associated with the bottom of the Guaritico River.

Tableau 2. Liste d'especes de poissons benthiques de la riviere Guaritico.

\section{RAJIFORMES}

POTAMOTRYGONIDAE

01 Potamotrygon orbignyi (Castelnau) 1885

02 Potamotrygon sp.

SILURIFORMES

AGENEIOSIDAE

03 Ageneiosus brevifilis Cuvier \& Valenciennes 1840

04 Ageneiosus ucuyalensis Castelnau 1855

CETOPSIDAE

O5 Cetopsis coecutiens (Lichtenstein) 1819

DORADIDAE

06 Leptodoras finnell Eigenmann 1940)

07 Megalodoras irwm Eigemann 1925

08 Pterodorus apurensis: (Fernändez-Yépezt) 1965

HYPOPHTHALMIDAE

09 Hypophthalmus edentalus Spix 1829

L.ORICARIIDAE

10 A phanotorulus jrankei 1sbrucker y Nijssen 1985

11 Hemiancistris sp.

12 Limatufichthys punctatus (Regan) 1914

13 Loricaria cotaphriata Linnaeus 1758

14 Loricarichthys maculatus (Bloch) 1794

15 Panaque nigrolineutus (Peter) 1877

16 Pseudohemiodon laticepts (Regan! 1904

17 Pterygoplichthys mu/tirradiatus (Hancock) 1824

18 Sturisoma rostratumes (Spix) 1829

19 Loricariidae yen. et sp. nov.

PIMELODIDAE

20 Callophysus macropterus (Lichtenstein) 1819

21 Duopalatinus sp.
22 Hemisorubim platyrhynchos (Cuvier \& Valenciennes) 1890

23 Pimelodidae gen. et sp. nov.

24 Pumelodella gracilis (Cuvier \& Valenciennes) 1890

25 Pimelodus blochii Valenciennes 1840

26 Pimelodus attissimus Eigenmann \& Pearson 19.42

27 Pinirampus pinirampu (Splx) 1829

28 Pseudoplatystoma fasciatum (Linnaeus) 1766

GYMNOTIFORMES

APTERONOTIDAE

29 .4dontosternarchus devenanzii Mago-Leccia, Lündber y Baskin, 1985

30 Adontosternarchus suchsi (Peters) 1877

31. Apreronotus bonapartii (Castelnau) 1855

32 Pormetgus sp. nov.

33 Sternarchowuon porcinum Eigenmann \& Allen 1842

14 Siernarchorhamphus muelleri (Steindachner) 1881

35 Sternurchorhynchus curvirostris (Boulenger) 1877

RHAMPHICHTHYIDAE

16 Rhomphichthys sp.

STERNOPYGIDAE

37 Disfocyctus conirostris Eigenman \& Allen 1942

39 Rhubdofichops eatswardi Lundberg \& Mago-Leccia, 1985

PERCIFORMES

CICHLIDAE

40 Geophagus altifrons Heckel 1840

SCIAENIDAE

4) Playioscion squamosaxsimus (Heckel) 1840

SOL.FIDAE

$\$ 2$ Hyporlinemus mentalis (Günther) 1862

Table 3. Fumilies, yenera, and speres for each of the orders trom the Guaritico River.

Tableau 3. Nombres de families, de genres et d'espoces de chaque ordre de la riviere Guaritico.

\begin{tabular}{lccrr}
\hline ORDER & FAMILIES & GENERA & SPECIES/ORDER & \% \\
\hline RAJIFORMES & 1 & 1 & 2 & 4,8 \\
SILURIFORMES & 6 & 24 & 26 & 61,9 \\
GYMNOTIFORMFS & 3 & 10 & 11 & 26.2 \\
PERCIFORMIES & 2 & 2 & 2 & 4,8 \\
PLEURONECTIFORMES & 1 & 1 & 1 & 2,4 \\
TOTAL. & 13 & 38 & 42 & 100 \\
\hline
\end{tabular}




\subsection{Diversity and abundance}

Highest diversity values were recorded between June and September with a maximum in August (Fig. 3). Diversity decreased between October and January with lowest values in December. Species richness values were highest in June (21 ssp.) and lowest in January (13 ssp.). Evenness showed a similar trend to diversity. Highest equity values were recorded in August while lowest values were recorded in December.

Considering the collections for the entire sampling period, the Siluriformes was the most abundant order $(53.3 \%$ ) followed by the Gymnotiformes $(44.7 \%$ ). The remaining orders represented only $2 \%$. Except in October and November, the Silurjformes was the dominant group throughout the sampling period. In December, this group represented almost $100 \%$ of the catches (Fig. 4). Except for the Gymnotiformes, the contribution of the other groups was small. In June, however, abundance of the Perciformes reached $20 \%$. Figures 5 a-c show the monthly relative abundance of each species.

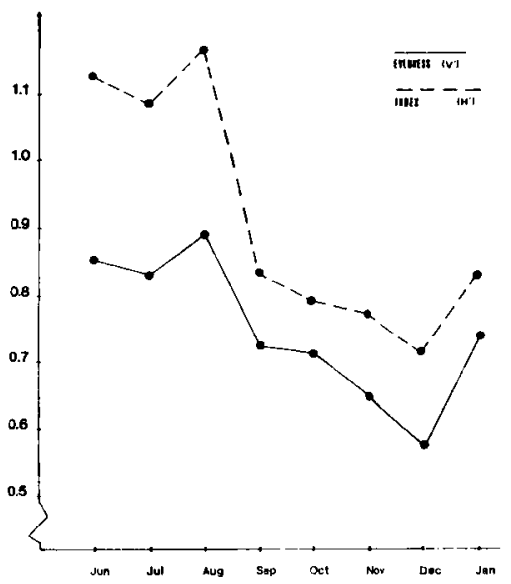

Fig. 3. Variations of fish diversity ( $\left.\mathrm{H}^{\prime}\right)$ and evenness. Fig. 3. Variatıons de la diversité $\left(H^{\prime}\right)$ el de l'équitabilité pisciaires.

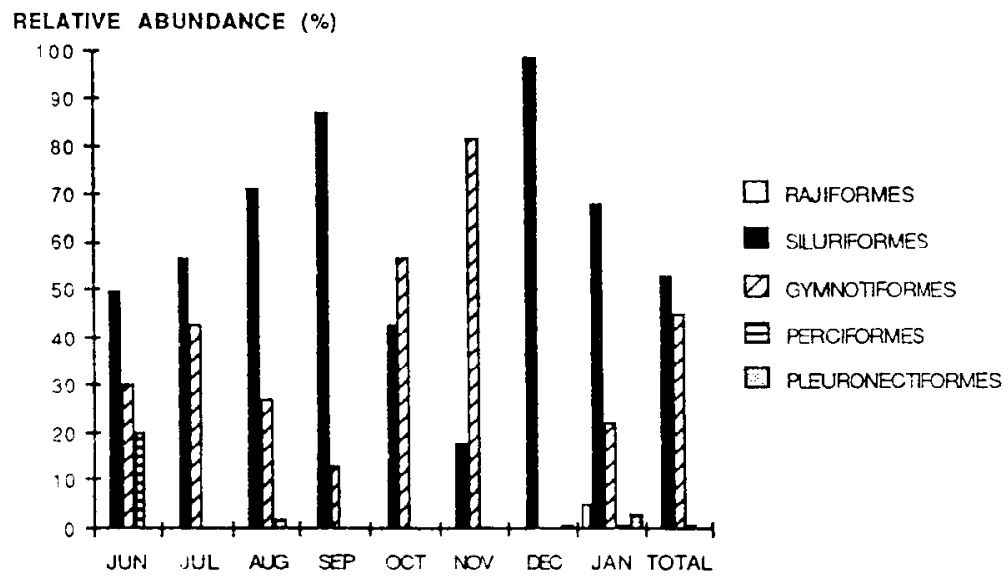

Fig. 4. Monthy relative abundance of each fish order.

Fig. 4. Abondance mensuelle relative des 5 ordres de poissons. 

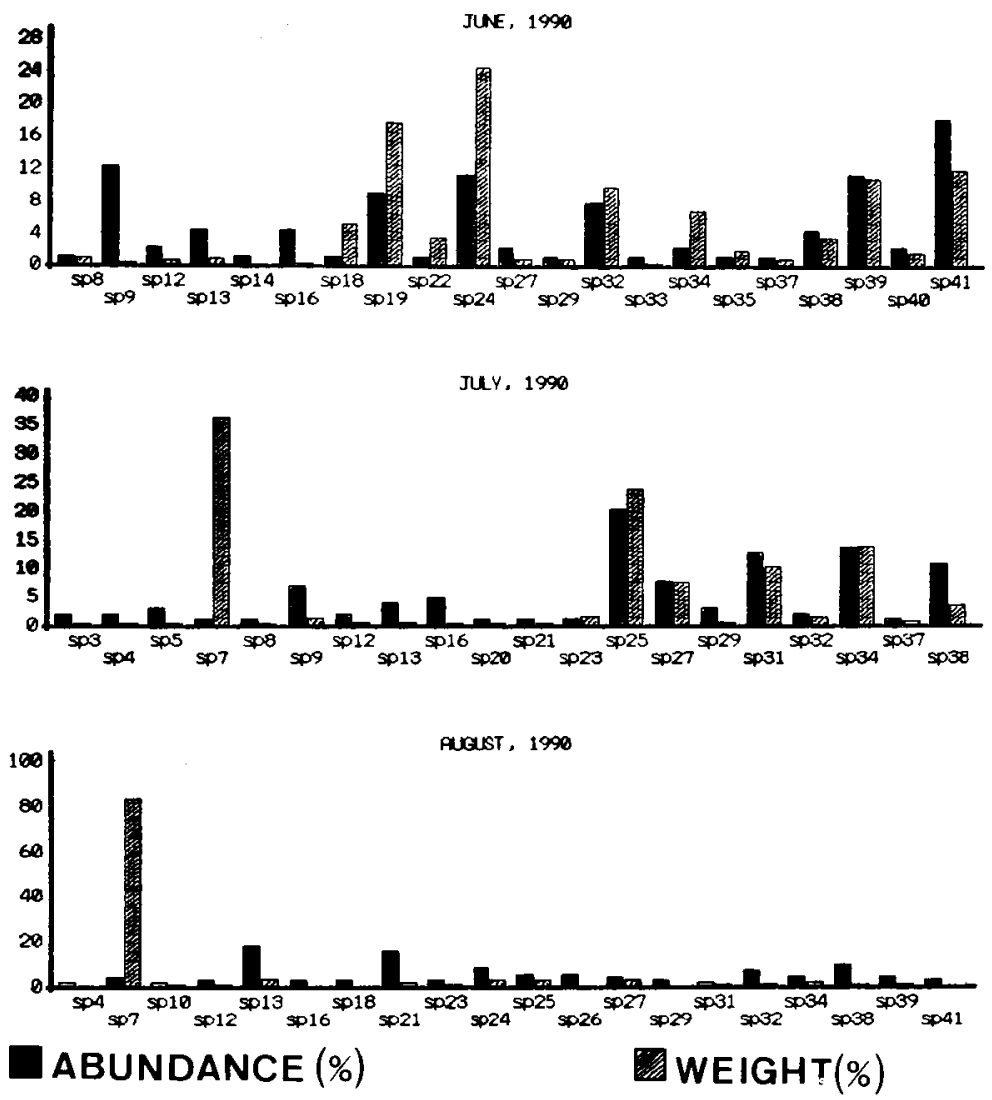

Fig. 5 a. Relative abundance and biomass of fish species for June-August, 1990 (codes on Table 2).

Fig. 5 a. Abondance relative et biomasse des différentes espèces de poissons en juin-août 1990 (code-chiffres : tableau 2 ).

June was the only month in which the most abundant species (Plagioscion squamossisimus, $17.8 \%$ ) did not belong to the Siluriformes or Gymnotiformes. This species was followed by Hypophthalmus edentatus (12.2\%). In July, Pimelodus blochii showed a $20.4 \%$ abundance followed by Sternarcho- rhamphus muelleri with $13.6 \%$. In August, abundance was similar among species except for Loricaria cataphracta and Duopalatinus sp. which dominated with $17.7 \%$ and $15.2 \%$, respectively. $P$. hiochii was again the most abundant species $\left(35.7 \sigma_{0}\right)$ in September, followed by Pimelodella gracilis 

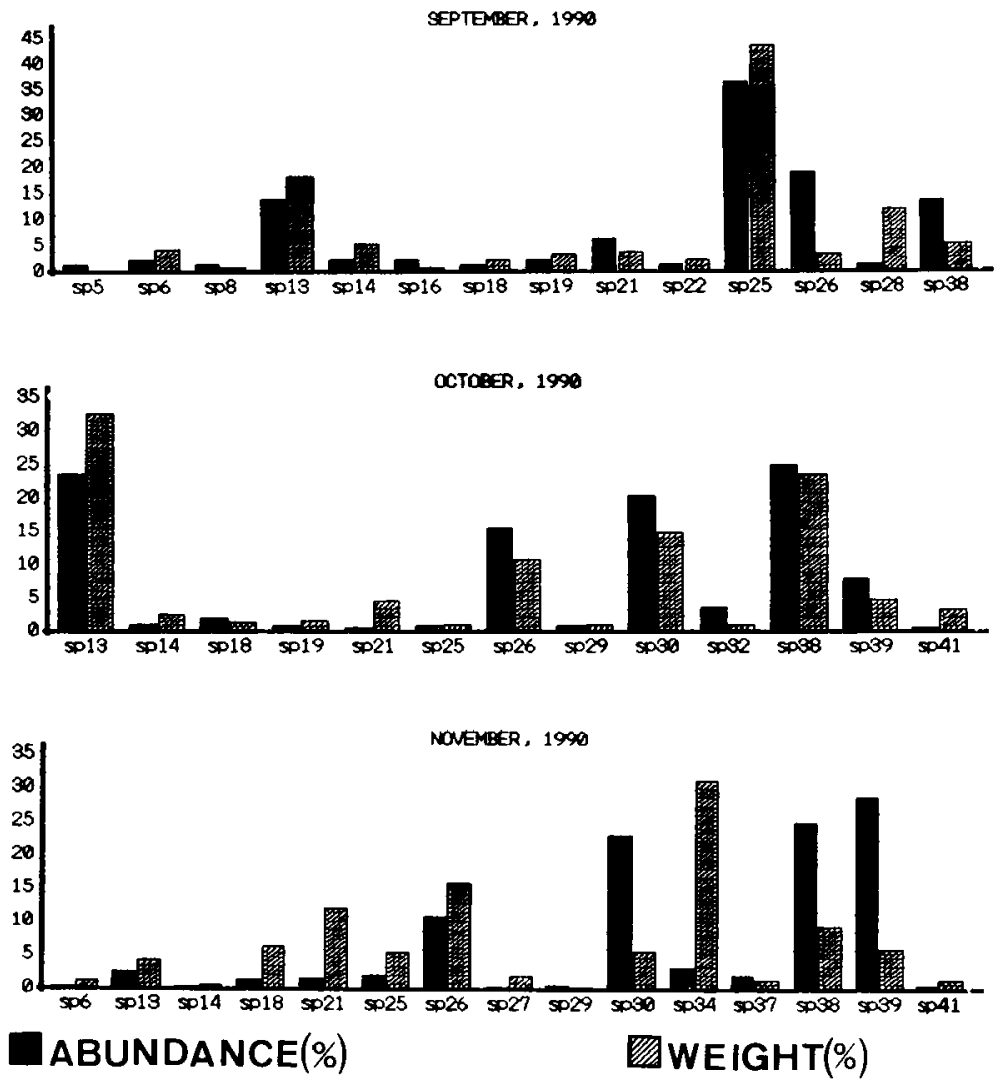

Fig. 5 b. Relative abundance and biomass of fish species for September-November, 1990 (codes on Table 2).

Fig. 5 b. Abondance relative et biomasse des différentes especes de poissons en septembre-octobre 1990 (code-chiffres : tableau 2).

(18.4\%). In October, a Gymnotiform (Eigenmannia macrops) showed highest abundance values (24.9 $\%$ ) for the first time. This species was followed by L. cataphracta $(23.4 \%)$. The Gymnotiformes clearly dominated in November (Rhabdolichops eastwardi,
$28.6 \%$; E. macrops, $24.9 \%$ ). In December, $L$. cataphracta and $P$. blochii showed again highest abundance ( $60.8 \%$ for both species). Finally, in January, $P$. blochii was again dominant $(32.7 \%)$. 

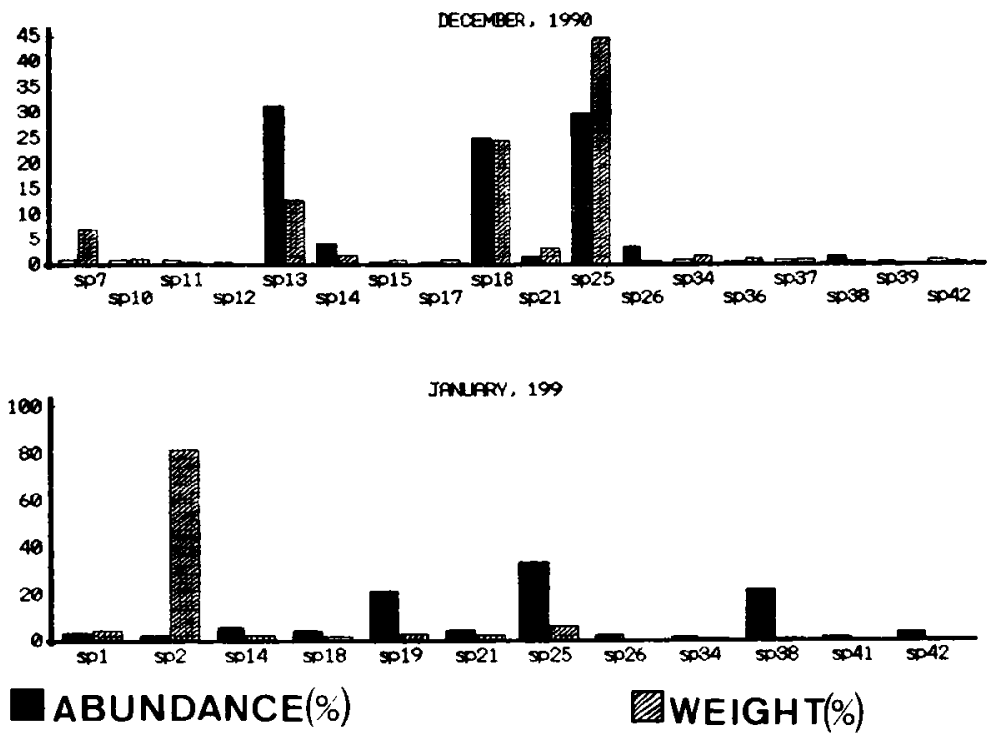

Fig. 5 c. Relative abundance and biomass of fish species for December (1990)-January (1991) (codes on Table 2)

Fig. 5 c. Abondance relative et biomasse des espèces de poissons en décembre 1990-janvier 1991 (code-chiffres : tableau 2).

In terms of ind. ha-1, lowest values were recorded between June and September with minimum values in August (115 ind. ha-1). Highest

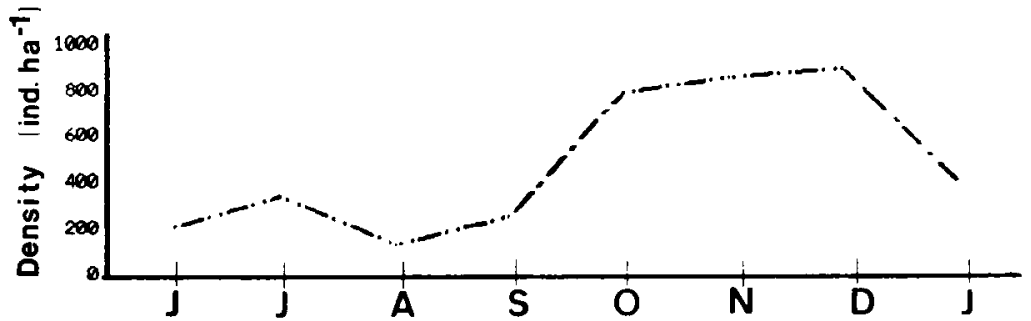

Fig. 6. Monthly fish abundance variations (ind. ha ${ }^{1}$ ).

Fig. 6. Variations mensuelles d'abondance pisciaire (ind. ha-1). 


\subsection{Biomass and CPUE.}

With respect to the total catch, the relative biomass indicated a dominance of the Siluriformes $(64.9 \%)$ followed by the Rajiformes $(21.5 \%)$, and Gymnotiformes $(12.9 \%$ ). The Perciformes and the Pleuronectiformes together indicated biomass values $<1 \%$. During the 8 months sampling period, biomass of the Siluriformes was the highest during 6 months $(65 \%)$. Only in November and January, was this group displaced by the Gymnotiformes $(52.9 \%)$ and by the Rajiformes $(85.1 \%)$, respectively (Fig. 7). The relative biomass values for each species are shown in Figures 5 a-c. In June the relative biomass value for Pimelodus altissimus was $24.2 \%$ while a new genus and species (Loricariidae) had a value of $17.4 \%$. In July-August, Megalodoras irwini had the highes biomass values $136.6 \%$ and $82.8 \%$, respectively). Only in September, did we observe highest abundance values corresponding to highest biomass values for one species $(P$. blochii, relative biomass: $42.9 \%$ ). In October, $L$. cataphracta was first $(32.3 \%)$ followed by $E$. macrops $(32.5 \%)$. In November, a Gymnotiform
(Sternarchorhamphis muelleri) showed the highest biomass values $(3.0 \%)$. P. blochii $(44.7 \%)$ and $S t u$ risoma rostrata $(24.3 \%)$ represented the most important species in December. Highest biomass of the Rajiformes $(81.3 \%$ ) was observed in January for the first time.

In terms of $\mathrm{kg} \cdot \mathrm{ha}^{-1}$, the lowest biomass value was recorded in June $\left(1.7 \mathrm{~kg} \cdot \mathrm{ha} \cdot{ }^{1}\right)$. In JulyAugust, biomass increased slightly to $9.6 \mathrm{~kg}$. ha-1 and then decreased in September-November. Highest values were observed in December-January (26.3 kg.ha-1 in January) (Fig. 8). The CPUE showed a similar pattern to biomass. Lowest values corresponded to June $(10.6 \mathrm{~kg} \cdot \mathrm{ha}-1)$ and highest values to January (164.4 kg.ha-1). (Fig. 9).

\section{Discussion}

Most of the species from the Guaritico River belong to the Orders Siluriformes and Gymnotiformes $(88.1 \%)$. This situation contrasts with records from other neotropical freshwater ecosystems characterized by the dominance of characoid fishes

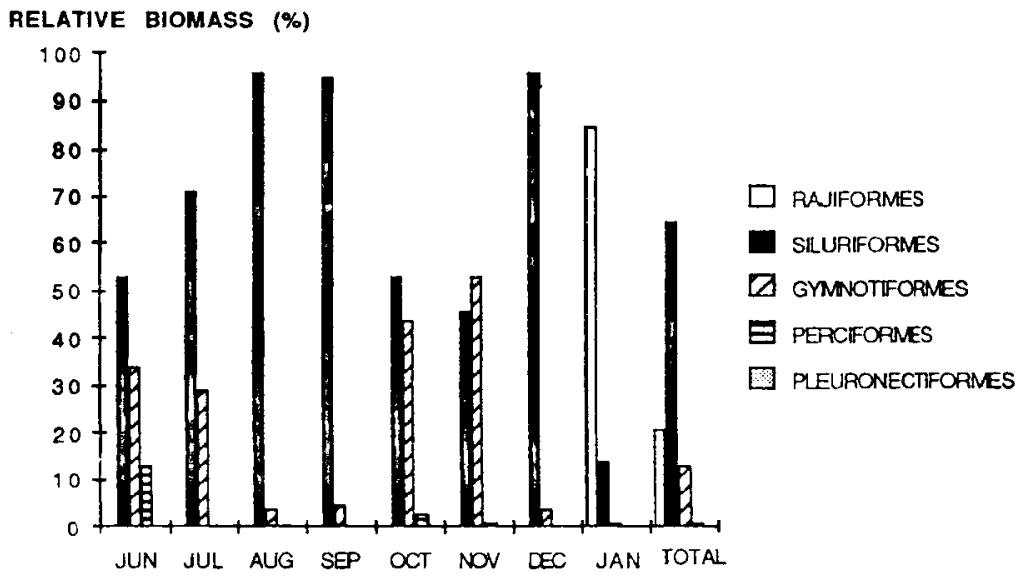

Fig. 7. Monthly variations of the relative biomass of fish order.

Fig. 7. Variations mensuelles de la biomasse relative des 5 ordres de poissons. 


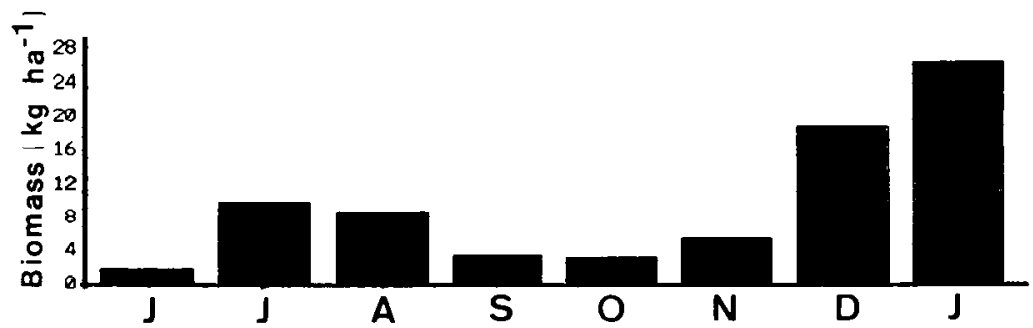

Fig. 8. Monthly fish biomass variations (kg.ha-l).

Fig. 8. Variations mensuelles de la biomasse de poisson $\left(\mathrm{Kg} . \mathrm{ha}^{-1}\right)$.

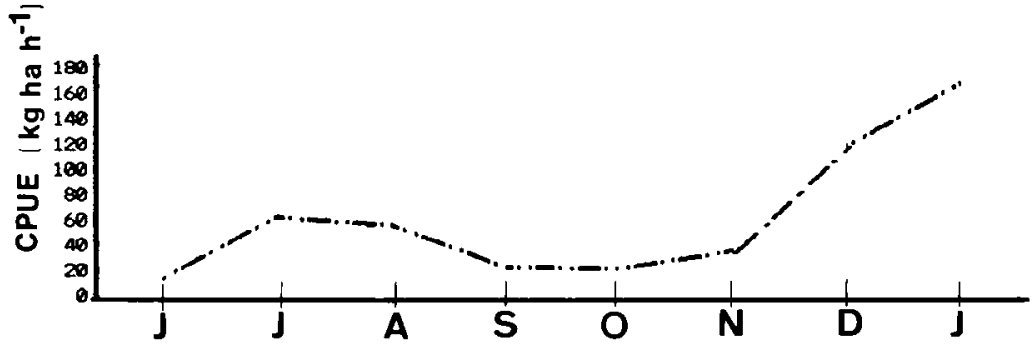

Fig. 9. CPUE variations (kg.ha.h-1).

Fig. 9. Variations de la capture par unité d'effort : CPUE (Kg.ha. $h^{-1}$ ).

(Lowe-McConnel 1975, 1987 ; Lowe-McConnell \& Howes 1981). Similar results have been reported for the benthic fish communities of the Apure River (Provenzano \& Castillo 1984 ; Provenzano et al. 1984 a, b, c) and of the Orinoco River Delta (LópezRojas et al. 1984 ; Ramos et al. 1982). In the lower Orinoco River, López-Rojas et al. (1984) distinguished two fish assemblages; one assemblage in the deepest sections of the main channel dominated by Gymnotiformes, and another one in adjacent shallower areas dominated by high richness of characoid fishes. In the Guaritico River, however, characoids specially the " piranhas" (Pygocentrus and Serrasalmus) represent accessory species. Their presence in our catches may be considered accidental as they were caught in the net while preying on other fishes.
In spite of the absence of complete fish lists, we compared the preliminary fish inventories of benthic species of the Guaritico and Apure rivers and of the Orinoco Delta. This comparison revealed a higher similarity between the Apure and the Guaritico River. The basic difference between these two rivers was the absence of certain genera in the Guaritico River : Aspredinidae (Xyliphius), Cetopsidae (Pseudocetopsis), Pimelodidae (Megalonema, Pimelodina, Platysilurus, Pseudopimelodus), Loricariidae (A pistoloricaria, Dentectus, Farlowella, Lamontichthys, Paraloricaria, Spatuloricaria). Apteronotidae (Sternarchella, plus two new genera) (Provenzano F., pers. comm.). The presence of other species from the Rajiformes, Clupeiformes, Perciformes, and Pleuronectiformes recorded by us in the Guaritico River and not yet recorded from the 
Table 4. Accompanying fish species found during the trawling of the bottom of the Guaritico River.

Tableau 4. Espèces de poissons accompagnants trouvées pendant le chalutage du fond de la rivière Guaritico.

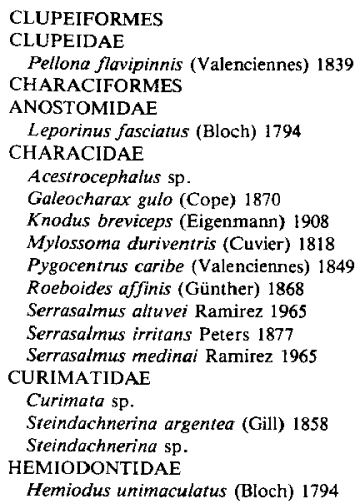

Apure River, is most probably due to the absence of more conclusive fish inventories than to the absence of these orders in the latter. With regard to the benthic fish fauna of the Orinoco River (excluding typically estuarine species), some genera are found in this region which have not yet been recorded from the Guaritico River : Engraulidae (Anchovia, Lycengraulis), Aspredinidae (Hoplomyzon, Platystacus), Doradidae (Opsodoras), Pimelodidae (Nannorhanmdia, Perugia), Hypopomidae (Steatogenys), Soleidae (Apionichthys).
The difference in the number of fish species from different rivers has been related to the size of the drainage surface and length of the main river channel (Welcomme 1985). This observation may explain the lower absolute number of fish species (alpha diversity according to Lowe-McConnell 1987) recorded from the Guaritico River in comparison to the Apure River and the Orinoco Delta (Table 5). The lower number of fish species from the Guaritico may also be the result of the smaller transects sampled by us (some $6 \mathrm{~km}$ ) compared to the transects sampled in the Apure River and Orinoco Delta. Another factor to consider in explaining the diversity and distribution of fish species of the Guaritico River is the type of water. The clear waters of this river differ from the white waters of the Apure and Orinoco rivers. The importance of water types on the distribution and diversity of neotropical fishes has previously been discussed (Weitzman \& Weitzman 1982). In the Apure River, the type of substratum has also been linked to the distribution of some Siluriform and Gymnotiform fish species (Provenzano \& Castillo 1984, Provenzano et al. $1984 \mathrm{a}, \mathrm{b}, \mathrm{c})$. In our study, the available data do not allow us to consider yet any possible relationships between the type of substrata and fish species.

In the Guaritico River, diversity and evenness showed a similar temporal pattern. Highest values were observed at high waters rather than low waters. A group of fish species was observed during both periods (Table 6 ) and at least 10 species of cat fishes (Siluriformes) were collected exclusively at high waters. These species may be migrating from the Apure River into the Guaritico River.

Table 5. Comparison among the number of fish species from each order from the Guaritico River, Apure and Orinoco River Delta. Tableau 5. Comparaison des nombres d'espèces de chaque ordre dans les rivières Guaritico et Apure et dans le delta de l'Orénoque.

\begin{tabular}{|c|c|c|c|c|c|c|}
\hline \multirow{2}{*}{$\begin{array}{l}\text { RIVERS } \\
\text { ORDERS }\end{array}$} & \multicolumn{2}{|c|}{ GUARITICO } & \multicolumn{2}{|c|}{ APURE } & \multirow{2}{*}{$\begin{array}{l}\text { ORINOCO } \\
\text { spp. }\end{array}$} & \multirow{2}{*}{$\begin{array}{c}\text { DELTA } \\
(\%)\end{array}$} \\
\hline & ssp. & $(\%)$ & ssp. & $(\%)$ & & \\
\hline RAJIFORMES & 2 & 4,8 & - & - & - & \\
\hline SILURIFORMES & 26 & 61,9 & 54 & 71,0 & 25 & 42,4 \\
\hline GYMNOTIFORMES & 11 & 26,2 & 22 & 29,0 & 25 & 42,4 \\
\hline PERCIFORMES & 2 & 4,8 & - & - & 3 & 5,1 \\
\hline PLEURONECTIFORMES & 1 & 2,4 & - & - & 1 & 1,7 \\
\hline OTHERS & - & - & - & - & 5 & 8,4 \\
\hline \multicolumn{7}{|l|}{ (Clupeiformes and } \\
\hline $\begin{array}{l}\text { (haraciformes) } \\
\text { TOTAL }\end{array}$ & 42 & 100 & 76 & 100 & 59 & 100 \\
\hline
\end{tabular}


Table 6. Presence and size range $(\mathrm{mm})$ of the species collected in the Guaritico River. Measurements for the Gymnotiformes $=$ total length ; for the Rajiformes = discal width ; other orders = standard length.

Tableau 6. Présence et taille moyenne $(\mathrm{mm})$ des espèces récoltées dans la rivière Guaritico. Mensurations pour les Gymnotiformes longueur totale ; pour les Rajifornes = largeur du disque ; autres ordres = longueur stardard.

SIZE RANGES (mm)

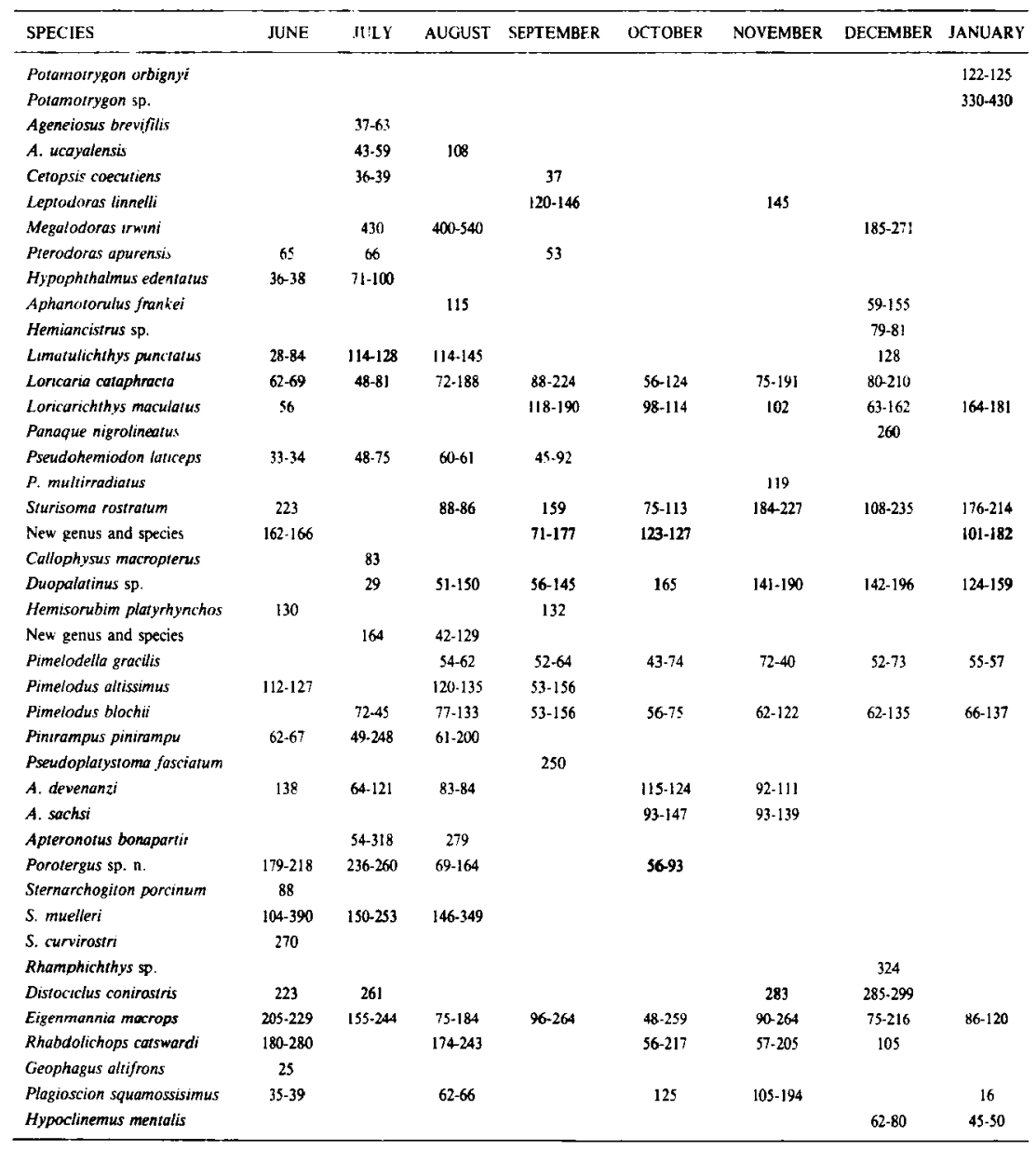


The overall fish abundance was higher at low water and lower at high water A simitar trend has been reported for Gymnotiform and Loricariidae fishes from the Apure River (Provenzano F ., unpublished). During the dry season, water level and current are reduced. At the onset of the rains and the subsequent increase in water level, water depth and water current are increased. These conditions may explain the smaller fist abundance. In our case, however, the smallest fish density was recorded at low water (January). Howevet, biomass values during this month wete highest due to the presence of Rajiform fishes (low abundaric and high biomass).

Similar to reports for the Orinoco River Delta (López-Rojas et al. 1984), we did not find a clear relationship between the CPUE and other variables (time of collections, lengths of trawling distances. depth of trawlings, type of substratal. There was, however, a relationship between the CPUE and the period of the year. Highest CPLIF value were recor ded at low water. Collections of fishes in the Giva. ritico River with the same fishn, gear ranged but ween 1-130 individuals per traw. In the Orinoco Delta, the number of fishes caught per trawl was always higher than 100 . This information is indicative of the high abundance and fish biomass found in the Orinoco Delta with respect to the Guaritico
River. The selectivity of the fishing apparatus, favouring the catch of smaller fishes, was observed in our work where we caught specimens ranging from $33 \mathrm{~mm}$ to $540 \mathrm{~mm}$ standard length (Megalodoras irwini) and $430 \mathrm{~mm}$ discal width (Potamotrygon sp.) (Table 6). The bottom of the Guaritico River showed an assemblage of fish species in different developmental stages ; species which inhabit the bottom for a period of their life-cycles (i.e. benthonic young stages of Siluriforms) or which inhabit the hottom through most of their developmental stages (Table 7).

Comparing our data with the information provided by Machado-Allison (1987) and by Penczak \& Lasso (1991), the highest biomass value $(26.3 \mathrm{Kg}$. ha ${ }^{1}$ ) recorded for the Guaritico River is low compared to mean values for other tropical freshwater river systemps.

\begin{abstract}
Acknowledgemen is
Wis wish to thank the Asouiación Amigos de Donana for the partial funding of this proiecl and O Castillo (FONAJAP), C.A. Invega, Fun dación $\mathrm{t}$, a Salle de Ciencias Naturales, and members of the farrily Matdorado for their logistic suppor1 : X. Elguezábal, H. Pintango and B. Mora (M A.R.N.R.) for their valuable assistance in the field work. We specially thank E. Vásquez for hix critical reading and for his English translation. $W$. Wilbert helped us in the editing of the English version. In addition we iecogrize A. Rial, R. Pérez and V. Ponte for their contribution in the production of the graphs; $\mathbf{H}$. López-Rojas, A. Machado- Allison and F. Provenzano (Universidad Central de Venezuela) who provided valuable comments and funaly we thank M. Garcia for her typing of the papier.
\end{abstract}

Table 7. Species and month of collection of juvenile stages associated with the bottom of the Guaritico River.

Tableau 7. Espèces et mois de capture des stades jeunes récoltés sur le fond de la rivière Guaritico.

\begin{tabular}{|c|c|c|c|c|c|c|c|c|}
\hline MONTHS & JUNE & IULY & AUGUST & SEPTEMBER & OCTOBER & NOVEMBER & DECEMBER & JANUARY \\
\hline A. brevifilis & & $\mathrm{x}$ & & & & & & \\
\hline A. ucayalensis & & $\mathrm{x}$ & & & & & & \\
\hline C. coecutiens & & $\mathrm{x}$ & $\mathrm{x}$ & & & & & \\
\hline P. apurensis & $\mathrm{x}$ & $\mathrm{x}$ & $\mathrm{x}$ & & & & & \\
\hline H. edentatus & $\mathrm{x}$ & $\mathrm{x}$ & & & & & & \\
\hline A. frankei & & & & & & & $\mathbf{X}$ & \\
\hline P. laticeps & $\mathbf{x}$ & $\mathrm{x}$ & & & & & & \\
\hline C. macropterus & & $x$ & & & & & & \\
\hline Duopalatinus sp & & $\mathrm{x}$ & $x$ & & & & & \\
\hline$P$. altissimus & & & & $\mathrm{x}$ & & & & \\
\hline P. blochii & & & & $\mathrm{x}$ & $\mathrm{x}$ & & & \\
\hline P. fasciatum & & & & $\mathrm{x}$ & & & & \\
\hline P. pinirampu & $\mathrm{x}$ & & & & & & & \\
\hline G. alififons & $\mathrm{x}$ & & & & & & & \\
\hline P. squamossisimus & $\mathrm{x}$ & & $x$ & & & & & $\mathrm{x}$ \\
\hline
\end{tabular}




\section{References}

Castilio O. 1988. - Aspectos biológicos y pesqueros sobre los peces comerciales del Bajo Llano con enfásis en los bagres (Orden Siluriformes). M. Sc., Universidad Central de Venezuela, Caracas, 112 p.

Castroviejo S. \& López G. 1985. - Estudio y descripción de las comunidades vegetales del "Hato El Frio " en los Llanos de Venezueal. Mem. Soc. Cienc. Nat. La Salle, 45 (124) : 79-151.

Cervigón F. 1982. - La ictiofauna estuarina del Caño Mánamo y áreas adyacentes. In D. Novoa (Comp.). Los Recursos Pesqueros del Rio Orinoco y su Explotación. Corporación Venezolana de Guayana, Editorial Arte, Caracas, 205-260.

Cervigón F. 1985. - La ictiofauna de las aguas costeras estuarinas del Delta del Orinoco en la costa Atlántica occidental Caribe. In A. Yañez-Arancibia (Ed.). Fish Community Ecology in Estuaries and Coastal Lagoons : Towards and Ecosystem Integration, 5 : 57-78.

Cervigón F. \& Novoa D. 1988. - Las Pesquerias Continentales en el Eje Orinoco-Apure. Perspectivas Futuras y Alternativas de Ordenamiento. Parte I : Sector Delta del Orinoco. (PSPA) Informes Técnicos para planes. DGSPOA/ITP/63, 109 p.

López-Rojas H., Lundberg J. \& Marsh E. 1984. - - Design and operation of a small trawling apparatus for use with dugout canoes. North Am. Journ. of Fish. Manag. 4 : 331-334.

Lowe-McConnel R.H. 1975. - Ecology of Fishes in Tropical Freshwaters: Their Distribution, Ecology and Evolution. Longman, London : $337 \mathrm{p}$.

Lowe-McConnel R.H. 1987. - Ecological Studies in Tropical Fish Communities. Cambridge University Press, London. $382 \mathrm{p}$.

Lowe-McConnel R.H. \& Howes G. 1981 . - Pisces. In H. Hulbert, G. Rodriguez \& N. Santos (Eds.). Aquatic Biota of Tropical South America, Part. 2, Anarthropoda. San Diego State University Press : 218-229.

Machado-Allison A. 1987, - Los peces de los Llanos de Venezuela : Un Ensayo Sobre su Historia Natural. Universidad Central de Venezuela, $\mathrm{CDCH}: 141 \mathrm{p}$.

Marrero C. 1987 . - Notas preliminares acerca de la historia natural de los peces del Bajo Llano. I. - Comparación de los hábitos alimentarios de tres especies de peces Gymnotiformes, en el Rio Apure (Edo. Apure, Venezuela). Rev. Hydrobiol. trop. 20 (1) : 57-63.

Marrero C. 1990. - La ecologia trófica de los Apteronotidae (Pisces, Teleostei, Gymnotiformes), en el rio Apure, Venezuela, enfocada a través de su morfología buco-cefálica externa y sus relaciones filogenéticas. Ph. D. dissertation, Universidad Central de Venezuela, Caracas : $76 \mathrm{p}$.

Novoa D. 1982 . - Los Recursos Pesqueros del Río Orinoco y su Explotación. Corporación Venezolana de Guayana, Editorial Arte, Caracas, 386 p.

Novoa D. 1986. - Resultados de los muestreos de fondo en el área estuariana del Delta del Rio Orinoco, Venczuela. IOG/FAO Workshop on Recruitment in Tropical Coastal Demersal Communities. Suplement 44.
Novoa D. \& Cervigón F. 1982. - Catálogo de los recursos pesqueros del Delta del Orinoco. In D. Novoa (Comp.). Los Recursos Pesqueros del Río Orinoco y su Explolación. Corporación Venezolana de Guayana, Editorial Arte, Caracas : $261-360$.

Penczak T. \& Lasso C. 1991. - Problems of estimating population parameters and production of fish in a tropical rain forest stream, North Venczuela. Hydrobiologia, 215: 121-133.

Ponte V. 1990 . - Recurso trófico utilizado por peces juveniles en dos áreas del Delta Inferior del rio Orinoco. Graduate thesis, Universidad Central de Venezuala, Caracas : $101 \mathrm{p}$.

Provenzano F. \& Castillo O. 1984. - La ictiofauna asociada al fondo del rio Apure. I. Gymnotiformes. Acta Cient. Venez., 35 (Supl. 1) : 469 (abstract).

Provenzano F., Brull O., Lasala J, \& Castillo O. 1984a. - La ictiofauna asociada al fondo del río Apure. Il. Familia Pimelodidae. Acta Cient. Venez, 35 (Supl. 1) : 469 (abstract).

Provenzano F., Brull O., Lasala J. \& Castillo O. 1984b. - La ictiofauna asociada al fondo del río Apure. III. Familia Loricariidae. Acta Cient. Venez., 35 (Supl. 1) : 469 (abstract).

Provenzano F., Brull O., Lasala J. \& Castillo O. 1984c. - La ictiofauna asociada al fondo del rio Apure. IV. Familias Doradidae, Ageneiosidae, Auchenipteridae, Hypophthalmidae, Cetopsidae y Bunocephalidae. Acta Cient. Venez., 35 (Supl. 1: 469 (abstract).

Ramia M. 1972. -- Cambios en la vegetación de las sabanas del Hato El Frío (Alto Apure) causados por diques. Bol. Soc. Ven. Cienc. Nat., 124-125: 57-80.

Ramos F., Novoa D. \& Itriago L. 1982. - Resultados de los Programas de Pesca exploratoria efectuados en el Delta del Orinoco. In D. Novoa (Comp.). Los Recursos Pesqueros del Orinoco y su Explotación. Corporación Venezolana de Guayana, Editorial Arte, Caraças : 162-191.

Scharger R. \& González R. 1973. - Estudio Agrobiológico preliminar. Sectores Bruzual y Mantecal. M.O.P. Dirección General de Recursos Hidraúlicos. División Edafología, Caracas.

Shannon G. \& Weaver W. 1949. - The Mathematical Theory of Communication. Univ. Illinois Press, Urbana : $177 \mathrm{p}$.

Sioli H. 1975. - Tropical rivers as expressions of their terrestrial environments. In F. Golley \& E. Medina (Ed.). Tropical Ecological System. Trends in Terrestrial and Aquatic Research. Springer-Verlag, Berlin : 275-288.

Stewart D., Barriga R. \& Ibarra M. 1989. - Ictiofauna de la Cuenca del río Napo, Ecuador Oriental : Lista anotada de especies. Politécnica 12 (4) : 9-63.

Weitzman S.H. \& Weitzman M. 1982. - Biogeography and evolutionary diversification in Neotropical freshwater fishes, with comments on the refugium theory. In G.T. Prance (Ed.). Biological Diversification in the Tropics. Columbia University Press, New York : 403-422.

Welcomme R.L. 1979. - Fisheries Ecology of Floodplain Rivers. London, Longman : $317 \mathrm{p}$.

Welcomme R.L. 1985. - River fisheries. FAO Fisheries Technical Paper, (262) : $330 \mathrm{p}$. 